
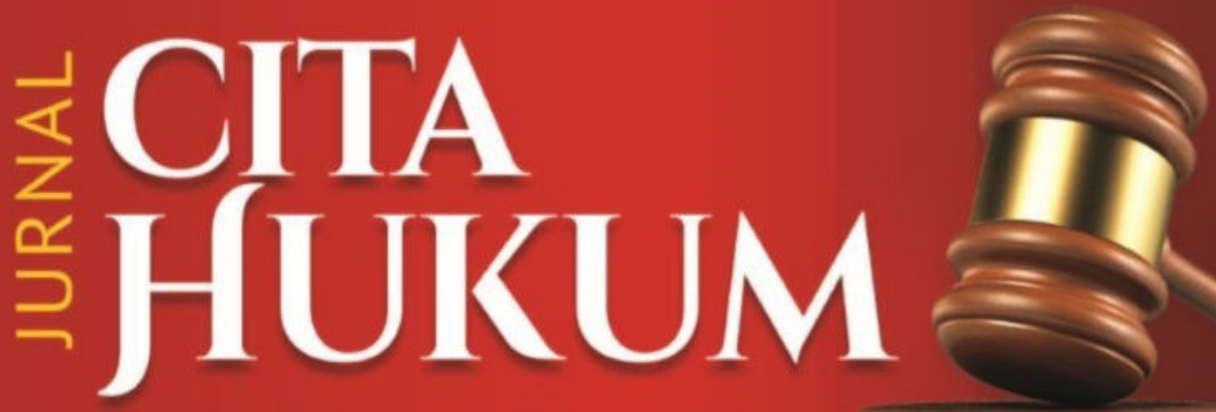

Indonesian Law Journal

- Effect Fake News for Democracy

Munadhil Abdul Muqsith \& Valerii Leonidovich Muzykant. (Moscow, Russian Federation)

- Utilization of Peatland Technology For Food Availability in a Legal Perspective Christine S.T. Kansil, Jeane Neltje Saly \& Adriel Michael Tirayo. (Jakarta, Indonesia)

- Preliminary Phase of the Right of Assessment in Iran and France with Emphasis on One Article to Respect Legal Freedom and Protection of Citizenship Rights Zahra Emadoleslami \& Hadi Ghorbani. (Islamic Republic of Iran)

- Command Responsibility of Autonomous Weapons Systems under International Humanitarian Law

Yordan Gunawan, Mohammad Haris Aulawi \& Andi Rizal Ramadhan. (Yogyakarta, Indonesia)

- Comparative Study of Conditions for the Purpose of Guarantee in Mudarabah Contracts Perspective of Islamic Jurisprudence and Iran's Civil Law Bijan Haji Azizi \& Marzieh Younesi. (Islamic Republic of Iran)

- Judicial Reform Under Democratic Consolidation in Indonesia Ibnu Sina Chandranegara, Syaiful Bakhri \& Muhammad Ali. (Jakarta, Indonesia)

- Legal Analysis of The Arrangement of Waqf Agricultural Agencies on Endowments Copyright In Perspective Legislation Nugroho Ari Wibowo, Nurul Hidayah \& Hafid Zakariya. (Surakarta, Indonesia)

- Direct Election of President and Vice President In Pancasila Perspective Sonny Taufan \& Risang Pujüyanto. (Jakarta \& Yogyakarta, Indonesia)

- Меры по предотвращению экологических коррупционных преступлений (Measures to Prevent Environmental Corruption Crimes) Ade Irma Elvira \& Latipah Nasution. (Moscow, Russian Federation)

\title{
Volume 7 Number 3 (2019)
}




\section{Jurnal}

\section{CITA HUKUM}

\section{VOLUME 7 NUMBER 3 (2019)}

JURNAL CITA HUKUM is Indonesian Law Journal published by Faculty of Sharia and Law, State Islamic University Syarif Hidayatullah Jakarta in Associate with Center for Study of Indonesian Constitution and Legislation (POSKO-LEGNAS) UIN Jakarta.

This journal specializes in Legal Studies and try to present various results of the latest and high-quality scientific research.

As an International Journal, all articles must be written in English or Russian, because they will be read online by millions of readers, both speakers of English and Russian.

JURNAL CITA HUKUM has been indexed at Web of Science (WOS) Web of Science (WOS) or Emerging Source Citation Index (ESCI)

Clarivate Analytics, DOAJ, EBSCO, DIMENSION, Microsoft Academic Search, and SINTA 2 and become a CrossRef Member since year 2015. Therefore, all articles published by JURNAL CITA HUKUM will have unique DOI number.

\section{INTERNATIONAL EDTTORIAL BOARD}

Prof. Carolyn Sappideen, Scopus ID: 6506771331 School of Law Western Sydney University, Australia

Prof. Alexander Fedorovich Malyy, Scopus Id: 57194874834 , Department of Constitutional Law, Kazan Federal University, Russian Federation

Prof. Razeen Sappideen, Scopus ID: 14041008300 School of Law Western Sydney University, Australia

Prof. Stanislav Shkel, Scopus Id: 56747984200 , Department of Constitutional Law, Ufa State Petroleum Technological University, Russian Federation

Prof. Stefan Koos, Bundeswehr University Munich

Prof. Muhammad Munir, Scopus ID: 54414595100, Department of Law, International Islamic University Islamabad, Pakistan

Prof. Euis Nurlaelawati, Scopus ID: 56247081700, Faculty of Sharia and Law, State Islamic University (UIN) Sunan Kalijaga Yogyakarta

Prof Abdul Gani Abdullah, Universitas Islam Negeri Syarif Hidayatullah Jakarta

Prof. Salman Maggalatung, Center for the Study of Constitution and National Legislation (POSKOLEGNAS), Indonesia

Assoc. Prof. Asep Saepudin Jahar, Scopus ID: 57156653300, Department of Economic Law Universitas Islam Negeri Syarif Hidayatullah Jakarta

Assoc. Prof. Ahmad Tholabi Kharlie, Thomson Reuters Id: R-5028-2017, Department of Family Law, Faculty of Sharia and Law, Universitas Islam Negeri Syarif Hidayatullah Jakarta

\section{EDITOR IN CHIEF}

Nur Rohim Yunus, Scopus ID: 57210890976, Thomson Reuters Researcher ID: F-3477-2017, ORCID ID: 0000-0003-27821266, SSRN ID: 2645355, SINTA ID: 5975443, Department of Constitutional Law, UIN Syarif Hidayatullah Jakarta, Indonesia

\section{MANAGING EDTOR}

Muhammad Ishar Helmi, Thomson Reuters Researcher ID: F-3345-2017, ORCID ID: 0000-0001-7060-8191, SINTA ID: 6199804, Department of Criminal LaN UIN Syarif Hidayatullah Jakarta, Indonesia.

\section{EDITORS}

Indra Rahmatullah, ORCID ID: 0000-0002-6160-4225, SINTA ID: 6200500, Department of Economic Law, Faculty of Sharia and Law, UIN Syarif Hidayatullah Jakarta, Indonesia.

Fitria Fitria, ORCID ID: 0000-0001-9733-1233, Department of International Law, York Law School, University of York, UK, United Kingdom.

Mara Sutan Rambe, ORCID ID: 0000-0001-5404-6635, SINTA ID: 6200494, Department Criminal Law, Faculty of Law, UIN Syarif Hidayatullah Jakarta, Indonesia. Erwin Hikmatiar, Thomson Reuters Researcher ID: F-3235-2017, ORCID ID: 0000-0003-4103-818X, SINTA ID: 6200141, Center for The Study of Constitution and National Legislation (POSKOLEGNAS), UIN Jakarta.

Arip Purkon, ORCID ID: 0000-0002-6195-9384, Department of Law, University of Malaya, Malaysia

\section{LANGUAGE EDITOR (ENGLISH AND RUSSIA)}

Raisa Shahrestani, Belgorodsky State University, Russia

Firsty Izzata Bella, State Islamic University (UIN) Syarif Hidayatullah Jakarta, Indonesia.

\section{ASSISTANT TOTHE EDITORS}

Imas Novita Juaningsih, State Islamic University (UIN) Syarif Hidayatullah Jakarta, Indonesia. Azizah Ratu Buana, State Islamic University (UIN) Syarif Hidayatullah Jakarta, Indonesia.

\section{Redaktur Office}

Faculty of Sharia and Law UIN Syarif Hidayatullah Jakarta Street Ir. H. Juanda 95 Ciputat Jakarta 15412 Phone. (62-21) 74711537, Faks. (62-21) 7491821 


\section{Jurnal

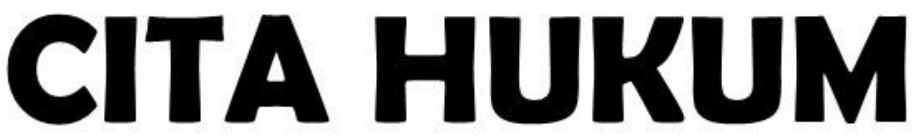

INDONESIAN LAW JOURNAL

Welcoming contributions from scientists, scholars, professionals, and researchers in the legal disciplines to be published and disseminated after going through script selection mechanisms, reviewing sustainable partners, and rigorous editing processes. 


\section{TABLE OF CONTENTS}

Effect Fake News for Democracy

Munadhil Abdul Muqsith, Valerii Leonidovich Muzykant

$307-318$

Utilization of Peatland Technology For Food Availability in a Legal Perspective

Christine S.T. Kansil, Jeane Neltje Saly, Adriel Michael Tirayo

Preliminary Phase of the Right of Assessment in Iran and France with Emphasis on

One Article to Respect Legal Freedom and Protection of Citizenship Rights

Zahra Emadoleslami, Hadi Ghorbani

Command Responsibility of Autonomous Weapons Systems under International Humanitarian Law

Yordan Gunaw an, Mohammad Haris Aulawi, Andi Rizal Ramadhan. $351-368$

Comparative Study of Conditions for the Purpose of Guarantee in Mudarabah

Contracts Perspective of Islamic Jurisprudence and Iran's Civil Law

Bijan Haji Azizi, Marzieh Younesi.

Judicial Reform Under Democratic Consolidation in Indonesia

Ibnu Sina Chandranegara, Syaiful Bakhri, Muhammad Ali.

$383-404$

Legal Analysis of The Arrangement of Waqf Agricultural Agencies on Endowments Copyright In Perspective Legislation

Nugroho Ari Wibowo, Nurul Hidayah, Hafid Zakariya. 405-416

Direct Election of President and Vice President In Pancasila Perspective

Sonny Taufan, Risang Pujiyanto.

Меры по предотвращению экологических коррупщионных преступлений (Measures to Prevent Environmental Corruption Crimes)

Ade Irma Elvira, Latipah Nasution. $431-450$ 
JURNAL CITA HUKUM (Indonesian Law Journal)

FSH UIN Syarif Hidayatullah Jakarta

Vol. 7 No. 3 (2019), pp.335-350, DOI: 10.15408/jch.v7i3.11542

\title{
Preliminary Phase of the Right of Assessment in Iran and France with Emphasis on One Article to Respect Legal Freedom and Protection of Citizenship Rights *
}

\author{
Zahra Emadoleslami, ${ }^{1}$ Hadi Ghorbani $^{2}$ \\ Faculty of Law, Islamic Azad University, Golbahar, Islamic Republic of Iran \\ d. \\ $\underline{10.15408 / \text { jch.v7i3.11542 }}$
}

\begin{abstract}
The right of citizenship in criminal law is one of the important cases in the field of human rights and has received attention from various human rights documents. In Iran's criminal law in various cases also respect to legal freedom and protection of citizenship rights. Besides trying to give more attention to citizenship rights based on fair assessment. An important question that can be raised in is how the regulation to respect the legal freedom and protection of citizenship rights in Iranian law proportional to French law in terms of a fair assessment? The findings from this survey show that there is a compilation of regulation respecting legal freedom and protecting citizenship rights. In addition, there is an internalization effort to pay attention the human rights in criminal justice, in the form of action to eliminate the aggression against the rights of citizen and this rule emphasizes cases that consistent with French law. In the rules of respect for legal freedom and protection of citizenship rights, such as the rights of convicted people in France, it has emphasized the existence of freedom, personal security, prohibition of torture, self-respect of the accused by defending their rights and protecting themselves.
\end{abstract}

Keywords: Freedom of law, human rights, citizenship rights, fair assessment, Iranian law, French law

How to cite (Turabian)

Emadoleslami, Z; and Ghorbani, H. "Preliminary Phase of the Right of Assessment in Iran and France with Emphasis on One Article to Respect Legal Freedom and Protection of Citizenship Rights" Jurnal Cita Hukum [Online], Volume 7 Number 3 (December 18, 2019)

\footnotetext{
${ }^{*}$ Received: July 15, 2019, revised: August 25, 2019, accepted: August 11, 2019, Published: Decembert 18, 2019.

${ }^{1}$ Zahra Emadoleslami is Master of Criminal Justice and Criminology, Faculty of Law, Islamic Azad University, Golbahar E-mail: ze.attorney55@gmail.com.

${ }^{2}$ Hadi Ghorbani is a Ph.D student Criminal Justice and Criminology, Faculty of Law, Islamic Azad University, Birjand. E-mail: dr.hadi1363@yahoo.com *Corresponding Author: ze.attorney55@gmail.com.
} 


\title{
Fase Awal Hak Penilaian di Iran dan Prancis \\ Dengan Penekanan pada Satu Artikel untuk Menghormati Kebebasan Hukum dan Perlindungan Hak Kewarganegaraan
}

\begin{abstract}
Abstrak
Hak kewarganegaraan dalam hukum pidana adalah salah satu kasus penting di bidang hak asasi manusia dan telah mendapatkan perhatian dari berbagai dokumen hak asasi manusia. Dalam hukum pidana Iran dalam berbagai kasus juga memberikan penghormatan terhadap kebebasan hukum dan perlindungan hak kewarganegaraan. Selain diupayakan untuk memberikan perhatian lebih terhadap hak kewarganegaraan berdasarkan penilaian yang adil. Pertanyaan penting dalam hal ini adalah seberapa besar aturan penghormatan terhadap kebebasan hukum dan perlindungan hak kewarganegaraan dalam hukum Iran berbanding lurus dengan hukum Prancis dalam sudut pandang penilaian yang adil? Temuan-temuan dari survey ini menunjukkan bahwa adanya kompilasi aturan penghormatan terhadap kebebasan hukum dan perlindungan hak kewarganegaraan. Selain itu, adanya upaya internalisasi untuk memberikan perhatian terhadap hak asasi manusia dalam peradilan pidana, berupa tindakan untuk menghapus tindakan agresi terhadap hakhak warga negara, dan aturan ini menekankan pada kasus-kasus yang relevan dengan hukum Prancis. Dalam aturan penghormatan terhadap kebebasan hukum dan perlindungan hak-hak kewarganegaraan, seperti hak-hak terpidana di Perancis telah ditekankan pada adanya kebebasan, keamanan pribadi, larangan penyiksaan, penghargaan diri orang yang tertuduh dengan membela hak-hak dan melindungi diri pribadi.
\end{abstract}

Kata Kunci: Kebebasan hukum, hak asasi manusia dan hak kewarganegaraan

\section{Начальные этапы права на оценку в Иране и Франции с опорой на статью об уважении правовой свободы и защиты гражданских прав}

\begin{abstract}
Аннотация
Право на гражданство в уголовном праве является одним из самых важных в области прав человека и привлекает внимание в различных документах по правам человека. В Иране уголовное право в различных случаях также уважает правовую свободу и сохранение гражданских прав и стремится уделять больше внимания гражданским правам на основе справедливого суждения. Важный вопрос, который может быть поднят в этом отношении, заключается в том, насколько правило уважения к правовой свободе и сохранению гражданских прав в иранском законодательстве прямопропорционально французскому законодательству с точки зрения справедливого суждения. Результаты этого исследования показывают, что существует свод правил, которые уважают правовую свободу и сохранение гражданских прав. Кроме того, предпринимаются усилия по интернализации, направленные на то, чтобы уделять внимание правам человека в сфере уголовного правосудия в форме ликвидации действий агрессии против гражданских прав. Данное положение подчеркивает случаи, которые соответствуют фрранцузскому законодательству. В правилах уважения правовой свободы и сохранения гражданских прав, таких как права осужденных во Франции, подчеркивается существование свободы, личной безопасности, запрета пыток, самооценки обвиняемого путем защиты их прав и себя.
\end{abstract}

Ключевые слова: правовая свобода, права человека, гражданские права, справедливое суждение, иранское право, французское право 


\section{Introduction}

The rule of respect to legal freedoms and protection of citizenship rights is very important for different reasons. This rule shows emerging a new method on the criminal justice in the field of accused people's rights and in fact, attention of this rule to accused person rights is an important achievement (Akhondi, 2011a).

Criminal judgment method that this rule is its agent, stresses that discovery of crime and protection of accused person rights have the same importance and differs a lot with the traditional criminal judgment that stressed on very hard encounter with accused persons. The discussion about rights before accused persons trail with respect to the rule of legal freedoms and protection of citizenship rights is very important. So far a comprehensive and independent survey hasn't been done in this connection, so increasingly importance of human rights stance in criminal laws has made doing this investigation a necessity. The rule of citizenship rights and respect to legal freedoms shows a new approach to human rights which besides using of local and national potentials in solving internal problems, utilizes of a worldwide value called human rights and stresses on using of human rights laws in internal rules. In fact, the approving this law which includes human rights concepts is in accordance with ongoing struggles for entering human rights values in internal rights of the nations (Akhondi, 2011b).

It seems that the Iranian legislature by adopting of France legislature has done efforts for supporting of accused person rights for respect to the rule of citizenship rights and protection of legal freedoms. In addition, both Iranian and French judicial systems, obeying international human rights documents have taken positive steps for strengthening accused person rights basis in just judgment (Akhondi, 2011C).

In this article, we have tried to investigate citizenship rights before trailing in Iran and France laws with emphasis on a single article of citizenship rights and legal freedoms rule. So at first, we explain the concept of pre-phase trail including crime discovery and preliminary investigations in Iran and France laws comparatively.

\section{Pre-phase Trail}

In the purpose of citizenship rights survey in the pre-phase trail in Iran and France laws, we first explain the pre-phase trail which means preliminary surveys and discovering crimes. 


\section{Discovery of Crime Phase}

This phase is very sensitive and exact in criminal justice, because the base of the dossier is in this phase and distinguishes the fate of the accused person. The purpose of discovery of crime is the actions that are done after informing of occurring the crime and protection of traces and reasons and arresting the accused person and holdup of his escape and collecting the related information concerning happened crime (Ashori 2016). The phase of discovery of crime is called to the process of occurring the crime, recognition of the accused person and collecting related reasons. According to police regulations, preserving traces and reasons of the crime, inspection, investigation, arresting the criminals and accused persons and preventing of their escape and hide are among police duties (Akhondi 2011).

The law of criminal justice method has attached various phases for trail and is an independent process and has its own regulations and orders. Discovery of the crime in any form is the duty of judicial retentive. The regulations of different countries have separated the phase of discovery of crime from other processes of trial and performing it, is the duty of judicial police. In Iran like France, the phase of discovery of crime has been separated from other processes of trial and is the duty of judicial police (Bagherpoor 2003).

\section{Preliminary Investigations}

Investigation means to survey and study for reaching to the reality that includes collecting reasons in benefit or harm of the accused person, issuance of an order for preventing of his escape or hide and making comment about his crime or innocence. In criminal laws of France, the famous decision called security and freedom has been approved and based on it, the decision of public prosecutor must pay attention to the possibility of accused person innocence (Moein 2014). When doing preliminary investigations, the judicial authority who questions the accused person may limit his freedoms based on some hypothesis regarding social security and morals. For example, the treaty of civil and political laws stresses that: anyone who is arrested must be informed about the reasons of it soon and as possible, the substitute actions should be used instead of detention (Zera' at 2011).

\section{Citizenship Rights of an Accused Person in Crime Discovery Phase}

In this discussion, citizenship rights of an accused person in the criminal discovery phase in Iran and France laws with emphasis on a single article of respect to legal freedoms and protection of citizenship rights are discussed. 
Preliminary Phase of the Right of Assessment in Iran and France with Emphasis On One Article to Respect Legal Freedom and Protection of Citizenship Rights

\section{Forbidding of Illegal Detention}

Freedom and personal security is one of the rights that have been formally accepted for all the people and also in international documents, governments are bound to protect them that based on in it, all the persons must have the right of freedom and forbidding it should be legally and necessarily by the order of judicial authority but as soon as possible justly judgment must be done about them, so that to be freed and other detainees should have the right to object to their arrests and compensation of their damages and illegal detention (Gholamreza Hojati Ashrafi 2017).

Commitments of governments in the field of protecting the freedoms rights and personal security have been paid attention in the treaties like international civil and political laws and European convention. In essential laws of Iran, some of the proofs of freedom right and personal security have been recognized and has stressed on forbidding of willfully and judicial authority must send the dossiers of the detainees' maximum in 24 hours to legal managers (Keshavarz 1997). Nevertheless, this rule has taken ongoing steps for releasing the accused person and stresses that all the activities must be based on the order of legal orders. An important element that has been paid attention in the law of respect to legal freedoms and protection of citizenship rights, is forbidding of arresting of people which shows it's leading in protecting human rights (Fardi 2012).

\section{Rights and Guarantees Regarding Accused Person Summoning}

In front of original and criminal laws, there are rules that organization, human forces and the way of forming and activities of the sources who must investigate the crimes and other related cases. Observing the ceremonies and guarantees regarding recalling and arresting accused persons, brings the feelings of justice and security for citizens of society and punishing the real criminals. Based on criminal judgments, recalling the accused persons were by sending letters and recalling by telephone was illegal and judicial authority must have enough and acceptable reasons for his summoning (Akhondi, n.d).

In recent laws, recalling of accused persons is done by special forms and they must be informed about the reason of their summoning. In addition, if inspection or assistant to public prosecutor wants to recall someone as accused person, they can't recall him with other title like witness because despite this surprising action from a judicial authority who should be honest, is immoral, from legal point of view also this behavior deprives accused person from his right 
of having lawyer during preliminary surveys (Sandiani, 2013). Therefore, criminal judgment law says: causing to understand of accusation to a person who hasn't been recalled as accused person for titles like a witness or aware, is forbidden and if he is accused after survey, based on regulations, he must be recalled as accused person in other time. Recalling must be communicated to the accused person and should be sent to his correct address and if his address is unknown, he must be recalled by the publication of advertisement in the newspaper.

According to criminal justice law, if the accused person is a legal person, in addition to a real person who accusation is aimed to him, a legal person also is informed to introduce his lawyer, because not introducing lawyer can't prevent judgment (Sandiani 2013). Observing increasing new communications methods among people, the legislature has decided to use them for informing recalling so the rule says: using of computerized and communications systems and devices like e-mail, fax, telephone and so on for presenting complaint or quarrel, referring dossier, recalling accused person, commutating judicial papers, according to electronically judgment is authorized (Sandiani 2013).

Enough reasons for recalling, mentioning the cause of recalling, result of not presence, are among the rights and guarantees related to accused person that we discuss about them in continuance.

\section{Enough Reasons for Recalling}

The first action that must be done about accused person, is recalling him for investigation, but we should pay attention to this point that although the grievance of the complaint for verification is enough, but presence of grievance or report of judicial clerks against someone isn't enough for his recalling and the crime that is attributed to anybody, must be based on the reasons that show his minimum participating in the crime. So the law stresses: inspector must not recall or arrest anyone as accused person without enough reason and if doing so, he will be punished (Akhondi, n.d).

As explained above, recalling accused person must have acceptable reason and this lawyer is necessary for establishing judicial security and legal authorities must pay attention to it exactly and the present method that as soon as the complaint or report is received, the order for recalling accused person is issued, isn't in accordance with human rights and legal regulations standards (Sandiani 2013). 


\section{Mention of The Recalling and The Result of Non-Presence}

In the law of criminal judgment method, the contents of summon are: Name and family name of the inductee - date, hour and place of the presence - mention the reason of recalling and the result on non-presence. But it has been stressed that judicial authority distinguishes it competent, he can avoid of mentioning two points in summons which are: the reason of recalling and result of non-presence.

a). Reason of recalling; Any recalled person is anxious about his situation and wants to know the reason of his recalling. Putting him in anxiety is against his human rights and in addition, judicial authorities can't recall anyone as complaint, aware or witness and then tell him that he is accused person, because this deceitful method isn't suitable for a judge and in most of the countries, this action counteracts the investigations and recalling (Gholamreza Hojati Ashrafi 2017). In Islamic republic of Iran, before approval of this rule, the judicial method was such that the exact title of the accusation wasn't written but it was stressed that he is recalled as accused person, because in the crimes that by distinction of judicial authority is against moral and security of society, the reason of recalling isn't written but accused person can go to judicial office and get information about the reason of the recalling (Keshavarz 1997).

b). The result of non-presence. Justice and logic necessitate that accused person be informed of his non-presence, because if he doesn't know what is the result of his non-presence, isn't logical especially in societies that people have not enough legal information (Ashori 2016).

c). Mention the right of accompanying lawyer when getting summons; Today not only right of having lawyer, but also impeachment this right to accused person is a human right and this is in the condition that in previous laws, the right of having lawyer wasn't mentioned and even there were some limitations at the start of investigations and questionings, but based on new rule, accused person can have a lawyer in preliminary investigations phase and this is written in his summons (Sandiani 2013).

\section{Accused Person Citizenship Rights in Preliminary Investigations Phase}

In this discussion, accused person citizenship rights in preliminary investigations phase is explained.

\section{The Right of Awareness of About Accusation Case}

The right of accusation case as one of the accused person essential rights in criminal system of Iran such as constitutions has been paid attention and police 
has been required in case of necessity of arresting accused person, the reason of his detention should communicate to him, because during questionings, he may found innocent and there seem no necessity for his arresting (Sandiani 2013).

The purpose of awareness of accusation is that the accused person should be aware of his crime, so that can defend himself because we can't expect someone to defend himself against unknown crimes and accusations. Awareness of accusation case is the starting point of the criminal judgment process and defend of the accused person. What should police and judicial retentive know is that, obtaining the necessity of detention of the accused person and his defense right (Akhondi 2011).

Special policies about important economic crimes bring limitations in this regard and police and judicial officials must have latitudes in these regards. Also in intermediate or low crimes, we must increase these latitudes so that the addressers be more and giving information be complete and fast.

Article 49 of criminal judgment method says: parents, wife, children, sisters, and brothers of accused persons can be aware of their detentions through judicial authorities and accountability to their relatives is necessary by preserving their social and family prestige (Gholamreza Hojati Ashrafi 2017).

In article 50 criminal judgment method, legislature says: detainee can use of telephone and other devices to inform his relatives about his arrest and officials must help him in this regard, except about political and security persons whom by the orders of judicial authorities (Gholamreza Hojati Ashrafi 2017).

This right according to criminal judgment method must be understood to accused person and receipt be taken and put in the dossier. The connection of the accused person with his family has been accepted with limitation, of course it has been said that: unless the judicial official necessarily distinguishes that accused person must not use of this right, but in France this right has been accepted absolutely and anyone who is detained, can inform his relatives with telephone about his situation (Sandiani 2013).

\section{The Right of Having a Lawyer}

The right of having a lawyer for accused persons from the first hours of arresting is recognized in law, so that the people that are arrested by police, in order to be able to support themselves against police behavior, have some rights such as calling one of their relatives to inform that they are arrested. Also, the accused person has the right to see his lawyer in the early hours of detention and if can't 
afford choosing a lawyer, request prison manager to have counsel briefed by the government (Zera' at 2011).

Constitutions council believes that the right of seeing a lawyer while detention is among the certain and undefeatable rights but in special cases such as terrorists and smugglers, only after 72 hours of detention, there is a possibility to see the lawyer (Akhondi, n.d).

In France criminal laws, the legislature has reformed some judicial and legal duties to have lawyers in some courts and based on this rule, presence of a lawyer in some courts are compulsory such as: the court of verification to crimes - administrative court - rehearing court - administrative council (Elliot 2006). France legislature in order to clear the preliminary investigations, has taken other important steps and in one of the recent rules, has been stressed that accused persons can be questioned only in presence of their lawyers, except the cases that regulations have declared. This rule says that the lawyers must after 5 administrative days be invited before any questionings or other legal actions about their appointed accused persons (Elliot 2006).

French legislature has done important reforms for accessing the lawyers to investigation dossiers so that after the first presence of an accused person in front of a judge and his hearings, dossiers will be available for lawyer except in holidays (Alihossein Najafi Abrandabadi 1999). Therefore, it can be seen that in France criminal judgment method in order to observe equality in defense rights of quarrel sides, two important distinctions have been predicted for their lawyers. Firstly, lawyers have the possibilities to have continual access to dossiers and secondly, they can have accessibility to all the contents of the dossiers (Tadayyon, 2010).

In addition, based on this rule the right of copy preparation of some of the papers of the dossiers by lawyers has been predicted. In this regard, lawyers must prepare a list of papers that want to have a copy of them and present it to the inspector and he should answer in 5 days and if not, it means his implicit agreement. But if the inspector opposes with this request, must have logical reasons and should be approved by the office manager. It should be noted that the papers are just for using of accused persons and giving them to others is forbidden (Keshavarz 1997).

As mentioned above, based on criminal judgment method in France, the right of accessing to investigation dossier is only possible for lawyers of two sides and complaint and accused person themselves aren't allowed to access to papers of the easier. In this regard, Strasbourg court has taken two different methods 
and at first in Foucher dossier, lack of accessibility of accused persons was distinguished against the element of equality of arms (Tadayyon, 2010). But some years later and in Menet dossier, the court didn't distinguish the lack of accessibility of complaint or his lawyer to dossiers against the law, because they are secret (Criminal Code of the French Republic 2016). Therefore court believes that this dossier is different with Foucher dossier, because in this dossier, the solicitor wasn't accused person and the concerned person has appeared in court with a verbal bill of indictment (Elliot 2006).

According to this idea, French legislature based on the element of equality of arm has brought about important arrangements for improving the presence of complaint and accused person in preliminary investigations phase that according to it, sides of the quarrel can request any action or investigation that leads to the discovery of the truth. It is worth mentioning that this right at first was predicted only for the public prosecutor and not for complaint and accused person (Tadayyon, 2010).

At last on June 15, 2000, by addition a rule to French criminal judgment method, this option was given to quarrel sides to request any action or investigation from the inspector to discover the truth. As French lawyers have mentioned, the aim of the French legislature for approving these regulations is establishing the complete equality between quarrel sides (Tadayyon 2010). In these cases, the inspector has required in case of non-accepting the request of the person, issue a logical order in a suitable time (Tadayyon 2010).

Finally the French legislature, in the continuance of this policy has predicted new regulations for the expertise and has taken important steps for more clearance (Criminal Code of the French Republic 2016). The new French criminal judgment method bounds inspector, in the time of issuance of expertise order, must at once send the orders to the public prosecutor and sides lawyers (Elliot 2006). Since the sending the order, two sides have 10 days' respite to request an inspector to change or complete the demands. In addition, this right exists for them to choose and introduce their elected experts to the high court of the country. If this request isn't accepted, the inspector must after 10 days of two sides requests, issue a logical order and after approval by the manager, is a definite decision (Guinchard 1999).

In addition, based on new regulations, the inspector has the authority that when the issuance of expert order lasts more than one year, asks the expert to announce his idea soon and inspectors must send it to the quarrel sides' lawyers (Alihossein Najafi Abrandabadi 1999). 
In Iran law, it seems that the request of investigations necessary for truth discovery hasn't been recognized as a right for quarrel sides. So although there isn't any prohibition for doing surveys by quarrel sides, judicial officials aren't obliged to accept these requests (Akhondi, n.d).

\section{The Right of Silence and Protest}

This right is among the defend rights of the accused person that means: right of silence and refuse to answer the questions of judicial officials about the accusation that has been propounded against him. according to element of exemption, hasn't any duty to prove his innocence and also oblige him to confess, so in Iran judicial system, the right of accused person silence is officially accepted and guaranteed and this silence can't be a reason for his crime and must be interpreted in the favor of accused person by the judge (Moein 2014).

The next discussion is about the duties of judges, especially judges of public prosecutor's office about declaring this right and in Iran laws, hasn't come obviously but a change in law says: before starting the questions, the inspector must tell the accused person to be careful about his remarks. then clearly talks about his accusation and its reasons and stresses that he confess or cooperation can reduce his punishment in court and then starts his questions (Ashori 2016).

The element of being rightful for the accused person about silence has been accepted in the new rule and says: an accused person can be silent and will be written in process-verbal so it is obvious that observing this rule is necessary for police and judicial officials in investigation phase (Zera'at 2011).

The right of silence is one of the results of the element of exemption and is among the defense rights of an accused person who must be aware of it before initial investigations and questionings. In regulations, this right hasn't been explained clearly and therefore, most of the accused persons aren't aware of this legal right and also the officials don't inform them, because there is no obligation about giving information to accused persons (Zera'at 2011). The right of protest to judge decision has been predicted in law and when an accused person goes to court, one of the duties of the inspector is deciding about an accused person, so that if he is free or must be sent to prison (Gholamreza Hojati Ashrafi 2017).

In the inspection system, the accused person hadn't any right to protest about the orders that led to his imprisonment and these orders were certain and imperative, but in mixed criminal judgment, after issuance of the order, the 
accused person has the right to protest and the legislature must guarantee this right (Sandiani 2013).

Article 32 of constitution says : no one can be arrested except by the order of rule, so arresting accused person without giving the right of protest is violating his rights and for solving this problem, the element of accused person right to protest must be officially accepted and if police and judicial officials do illegal actions must be punished (Gholamreza Hojati Ashrafi 2017). Keeping the accused person in the house of detention without explaining the charge or deciding and issuing orders, are violating human rights and unfortunately the right of protest for the accused person about his detention hasn't been emphasized in-laws (Sandiani 2013).

\section{Accused Person Rights in Release Order}

Based on the criminal justice method, if complaint requests finishing the trail, the court issues release order. Although in this rule, the court has been mentioned most of the lawyers believe that finishing the quarrel can be done by the judges of the public prosecutor's office, too (Akhondi 2011).

The aim of finishing the quarrel is that complaint can withdraw his grievance temporarily but can have a complaint regarding the dossier. Based on present regulations, this can be done in private crimes and with the request of complaint (Ashori 2016). But in new rule, some changes have occurred that are concerned to accused person and says: inexcusable crimes, complaint can request finishing the quarrel before issuance of indictment and so, public prosecutor issues the order and complaint can have requested his renewed prosecution just once and in one year after finishing the quarrel (Gholamreza Hojati Ashrafi 2017).

The important point in this article is "with the agreement of accused person, because people may baselessly complain each other and during investigations, request finishing quarrels, so accused person agreement can prevent such actions" (Sandiani 2013).

\section{Compensate for Detention Days}

If the quarrel leads to forbidding of prosecution or exemption of accused person, he can complaint another side for his defamation and also requests compensation, because the rights that legislature has given to complaint may be abused and in France regulations, special rules exist in this regard for innocently accused person and if judicial authority distinguishes that the quarrel has been 
with the aim of abuse, the other side is convicted to pay up to 15000 euro (Criminal Code of the French Republic 2016).

In fact this action is known as violating the judicial process and France legislature has predicted simple, fast and cheap methods that after 3 months of absolute forbidding quarrel, accused person can request compensation his losses and damages by the complaint and judicial authorities must look after his application and if it is proved that complaint has presented unreal grievance, he will be convicted to compensate the losses and damages of the order side (Elliot 2006).

\section{Conclusion}

In this study, we investigate these questions that the law of respect to legal freedoms and protection of citizenship rights in Iran rules in comparison with France rules in the phase of pre-judgment, how much is in accordance with justly judgment standards?

The results of the investigation show that the law of respect to legal freedoms and protection of citizenship rights are very important in various

persons. This law shows emerging a new criminal justice policy in the field of accused people's rights and in fact attitude of this law to accused persons, at least after the Islamic revolution is unexampled.

The results of the investigation show that the criminal law of Iran has taken important steps in the direction of observing personal rights and freedoms and human greatness, especially in the preliminary investigations phase. these changes are observing of human rights standards inserted in international human rights documents like Islamic republic constitutions that based on which judicial authorities aren't obliged to observance justly judgment elements and defense rights of accused persons. Many of citizenship rights that have been emphasized in respect to legal freedoms and protection of citizenship rights have been taken from France laws and conformable with citizenship rights in human rights documents. Based on article 5 of the new criminal judgment method, the accused person must urgently be informed about the case and the reasons for his accusation and access to lawyer and defense rights in the rule. The article 6 of this law says: accused person, loser, witness and other connected people must use their rights and judicial authorities who don't observe these rules, will be punished (Gholamreza Hojati Ashrafi 2017). 
The right of having a lawyer in preliminary investigations phase is among the citizenship rights that have been paid attention in the criminal judgment of Iran like France. It must be mentioned that the possibility of appointing counsel briefed by the government for the accused person in preliminary investigations phase for life imprisonment or execution accused persons have been predicted (Sandiani 2013).

The presence of lawyer in this phase was assurance for his delegated but he wasn't allowed to study the dossier or interfere in questionings process, but in 2011 many reforms were done about this law such as possibility of studying dossier, participating in police investigations and asking questions that help to discover the truth (Hojati Ashrafi, 2017). Iranian legislature, avoiding of the inspection system in police investigations phase, for the first time allowed the right of the meeting of the accused person with his lawyer in the preliminary process, but it isn't clear and more reforms in this regard are necessary (Hojati Ashrafi, 2017).

In France laws, surveillance is an important phase in the judicial process and for observing the defense rights of the accused person, several regulations have been predicted in this regard and French legislature has tried to prevent abuses and violating accused person rights by limiting rules and regulations (Elliot 2006).

Approval of the law of respect to legal freedoms and protection of citizenship rights shows the Iranian legislature efforts to remove the legal deficits about the situation and fate of detained accused person. Few articles talk about this matter, but because of shortages of this rule which most important of them are lack of guarantee for performance by agents and responsible authorities in doing their legal duties, legislatures have tried to solve these problems by paying attention to the criminal laws of other countries such as France.

\section{References:}

Akhondi, M. Practical Criminal Judgment Method. Vol. V. Ministry of Culture and Islamic Guidance Publications. 2011.

Akhondi, M. Practical Criminal Judgment Method. Vol. 2011. Ministry of Culture and Islamic Guidance Publications. 2011.

Akhondi, M. Practical Criminal Judgment Method. Vol. II. Ministry of Culture and Islamic Guidance Publications. 2011. 
Akhondi, M. Practical Criminal Judgment Method. Vol. I. Ministry of Culture and Islamic Guidance Publications. 2011.

Abrandabadi, A.N. "Organized Criminals in French Criminal Laws." Journal of Law Research 1 (23). 1999.

Ashori, M. Criminal Judgment Method. Vol. II. Tehran: SAMT Publications. 2016

Bagherpoor, Y. "Criminal Cases in Iran and France Laws." Journal of Strategic Management Investigations 30-31 (39): 74-112. 2003.

Criminal Code of the French Republic. 2016.

Elliot, C. French Legal System. 2nd ed. London: Longman. 2006.

Fardi, P. Comparative Criminal Judgment Method. Tehran: SAMT Publications. 2012.

Ashrafi, G.H. Collection of Civil and Basic Laws. Ganj-e-Danesh Publications. 2017.

Guinchard, S. Vers Une Democratie. Justice Dalloz. 1999.

Keshavarz, B. The Law of Establishing General and Revolutionary Courts. Tehran: Keshavarz Publications. 1997.

Moein, M. Moein's Persian Encyclopedia. 27th ed. Tehran: Amirkabir Publications. 2014.

Sandiani, M. "Legal Rights of Accused Persons." Master Thesis. 2013.

Tadayyon, A. "Assessment of Penal Proof in Iranian and French Procedure Systems." Comparative Laws Studies 14 (2): 57-78. 2010.

Zera'at, A. Criminal Judgment Method in The Present Judicial System. Ghanounmadar Publications. 2011. 
Zahra Emadoleslami, Hadi Ghorbani

350 - JURNAL CITA HUKUM (Indonesian Law Journal). Vol. 7 Number 3 (2019). P-ISSN: 2356-1440.E-ISSN: 2502-230X 


\section{JURNAL}

\section{CITA HUKUM INDONESIAN LAW JOURNAL}

\section{TECHNICAL GUIDANCE FOR AUTHORS OF CITA HUKUM JOURNAL}

1. Article must be original, not plagiarism, unpublished, and not under review for possible publication in other journals.

2. Article should be concept, research-based, and toughts;

3. Article should be written in English

4. Article must contain of Law Science

5. Writing Guidance as follows:

a. Title is written by Capital maximum 12 words in the center

b. Name of authors are written completely, no degree, institutional affiliation, address, and email.

c. Abstract is written in English maximum 250 words.

d. Systematycs of article:

1) Title

2) Name of authors (no title), name of affiliation, email

3) Abstract

4) Keywords, between 3-5 words

5) Introduction

6) Sub title (if need it)

7) Closing

8) Bibliography (The bibliography list contains all references in text originating from sources that are relevant and at least up to date (last 10 years).

e. Paper Sizes are $17,5 \times 24 \mathrm{~cm}$, up $2,5 \mathrm{~cm}$, down, $2,5 \mathrm{~cm}$, right $2,5 \mathrm{~cm}$, and left $2,5 \mathrm{~cm}$

f. Length of article is between $18-20$ pages with 1.0 line spacing, Palatyno Fond Style with 10 size.

g. Rule of citation. Direct citation if word is more than 4 lines separated from the text with 1.0 spacing with 9 font. However if citation less than 4 lines, it should be integrated in the text with double apostrof both in the first and in the end. Every citation is given number. Citation system is body note and use turabia system. Every article, book, and other source should be citated on the reference.

h. Citation for Quran and Hadist. For verse citation contains name of surah, number of surah and number of verse example: (Qs. Al Mumin [40]: 43). For Hadis citation, mention name of Perawi/Author, example (H. R al-Bukhari and Muslim) and printed hadist version. Hadist must be from standar hadist books (Kutub at-Tisah). 
i. Bodynote is written by Palatino Linotype style, size 10, for any sources as: (Yunus, 2014: 144).

j. Bibliography. Bibliography is written alphabeticaly, last author's name is in the first of name, example:

1) Book: Soekanto, S. Pokok-Pokok Sosiologi Hukum, Jakarta: Rajawali Press, 1986.

2) Translated Book. Example: Pound, R. Pengantar Filsafat Hukum: Book III, translated by Moh. Radjab, Jakarta: Bharata, 1963.

3) Journal, example: Rohim, N. "Kontroversi Pembentukan Perppu No. 1 Tahun 2013 tentang mahkamah konstitusi dalam ranah kegentingan yang memaksa", Jurnal Cita Hukum, Volume 2 Number 1 (2014).

4) Article as a part of book (antology). example: Juwana, H. "Penegakan Hukum dalam Kajian Law and Development: Problem dan Fundamen bagi Solusi Indonesia", in Muhammad Tahir Azhary, Beberapa Aspek Hukum Tata Negara, Hukum Pidana, dan Hukum Islam, Jakarta: Kencana Prenada Media Group, 2012.

5) Article from internet, example: Kharlie, Ahmad Tholabie, "Problem Yuridis RUU Syariah" in http://ahmadtholabi.com/2008/03/03problem-yuridis-ruu-syariah, downloaded on March 20, 2012.

6) Article from magazine, example: Susilaningtias, "Potret Hukum Adat pada Masa Kolonial," in Forum Keadilan, No. 17, August 20, 2016.

7) Article in Seminar, example: Asshidiqqie, Jimly, "Kedudukan Mahkamah Konstitusi dalam Struktur Ketatanegaraan Indonesia," paper presented on public lecture at faculty of law Universty Sebelas Maret, Surakarta on March 2, 2014.

k. Closing, article is closed by conclusion;

I. Short biography: author's biography contains full name, title, institution, education and other academic experts.

6. Every article that doesnt fufill all requirements to this guidance will give it back to the author for revision.

7. Article must be submitted to editors at least 3 months before publishing (April, August, and December) with uploading via OJS to http://journal.uinjkt.ac.id/index.php/citahukum or e-mail to jurnal.citahukum@uinjkt.ac.id.] 
in Collaboration with :

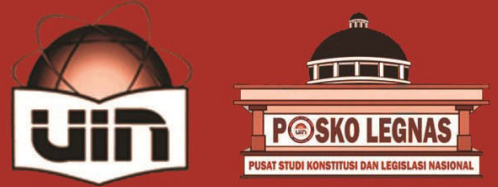

Indexed by :
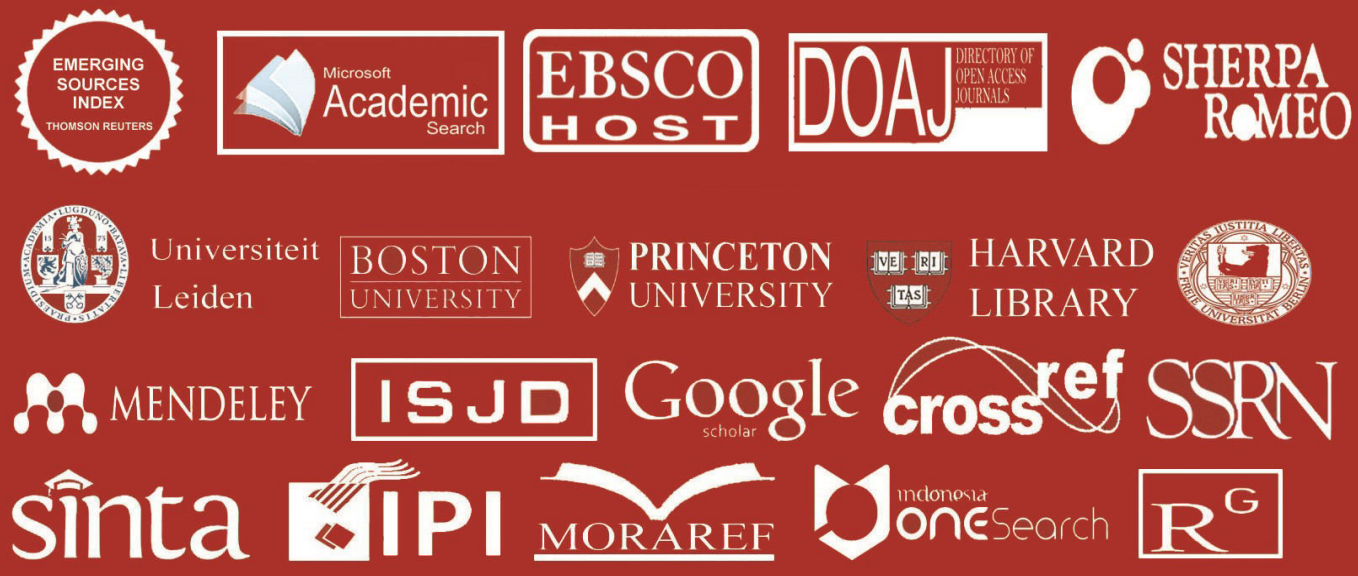

JURNAL CITA HUKUM is a peer-reviewed journal on Indonesian Law Studies published biannual (June \& December) by Faculty of Sharia and Law Universitas Islam Negeri Syarif Hidayatullah Jakarta in cooperation with Center for the Study of Constitution and National Legislation (POSKO-LEGNAS). JURNAL CITA HUKUM aims primarily to facilitate scholarly and professional discussions over current developments on legal issues in Indonesia as well as to publish innovative legal researches concerning Indonesian laws.
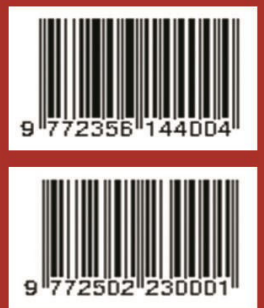